\title{
Teaching Methods and Teaching Effect Relationship Empirical Research *
}

\author{
Rui Kong, Sha Yu, Junwei Chen \\ China University of Geosciences (Beijing) Humanities \& Economic Management School, Beijing, China
}

\begin{abstract}
The purpose of this case study is to obtain the level of effectiveness of using the teaching methods system, to provide the appropriate basis for rationality of teaching and learning activities designed. The corresponding data are obtained by the research of MBA students who participate in the course of Marketing Management in recent years. Depending on the data, the authors have found four main features from the relation between teaching methods and effect. First, the three basic traditional teaching methods include " classroom teaching”, “ discussion" and "case study" which must be integrated in order to be more effectiv, and make the experiential learning experience more popular. Second, a variety of teaching methods to enhance the overall quality might be under the influence of the length of service and students' age. Third, the use of rational design process and the convergence of the state of teaching methods, can be more effective in limited teaching practice. Fourth, the current teaching methods system with reasonable time ratio is able to get good teaching effect. Meanwhile, the results of the study and laws also provides a basis for teaching methods of other MBA management courses.
\end{abstract}

Keywords-MBA teaching; teaching methods; the overall quality

Back in the 1980s, former Prime Minister Zhu Rongji once said : For professional education, the most important thing is management education. China lacks management personnel to a great degree. During the 22 years, from 1991 to the present, through continuous improvement and adjustment, whether it is education or management activities of China's MBA education has achieved greatly. This can be seen from the number of the year enrollment expands by 400 times, colleges expand by 25 times and huge market demand has been created. ${ }^{[1][2]}$

China's MBA education in the development process has integrated into the world. Tsinghua University took the lead in the MBA program among Chinese Universities to cooperate with foreign universities, and obtained the AACSB and EFMD EQUIS certification respectively. ${ }^{[3]}$ The education model changes from imitating the Western model to localized education. [4] Chinese companies are constantly learning and in search of the best mode of operation, and renovate Western and Japanese management model by adding Chinese elements to participate in international competition. Therefore, to promote the rapid development of China's MBA education also makes the MBA educators continue to study China characterized education model.

Recently, the country launched the "on deepening the reform of postgraduate education of opinion", which states that : The admission policy should continue tilt toward Specialized Master to make the proportion of Specialized Master to Academic Master reach 1:1. At the same time, that the distinct problem in postgraduate training is the lack of innovation and practical ability of students. The quality should be improved. ${ }^{[5]}$ Therefore, to conduct empirical research of issues related to the MBA teaching quality has practical significance.

\section{RESEARCH STATUS}

\section{A. Introduction of data access}

Through analyzing the database obtained from CNKI, it has found high ratio of articles about research the development direction of Chinese MBA Education, less than $10 \%$ articles about teaching programs and models, and only less than $1 \%$ articles about teaching quality assessment.

Through searching Web of Knowledge (SCI, SSCI, ISTP, CSCD) database, 154 relevant research papers are found. The authors are mainly from the United States, Romania, Greece, Australia, Canada and China. The majority study subjects are about MBA education in the United States and Europe.

\section{B. Introduction of domestic research}

Students' softpowers are constantly strengthened, such as character building, knowledge integration and enriching experience. ${ }^{[3]}$ MBA education is a professional education for senior manager and training entrepreneurs with leadership capabilities. Then, that teaching quality management and quality control and evaluation, student satisfaction need be upgraded constantly ${ }^{[6]}{ }^{[7]}{ }^{[8]}$ by enhancing the evaluation the level of MBA students' dissertation and the evaluation of classroom teaching. ${ }^{[9]}$

Quality of innovation and practical ability training is the basic quality requirements of MBA education. Especially the Chinese MBA students' younger age trend is more concerning. ${ }^{[10]}$ Developing training direction, introducing the industrial events into teaching, double teachers teaching model, entrepreneurs forum, clubs, and other industry experience-based learning environment design have been constantly promoted. ${ }^{[1]}$ Experiential learning is carried forward. The development of business information and a variety of new forms of entrepreneurial planning encourage MBA students to participate in economic activities to learn. ${ }^{[11]}$

Localized design of courses and course structure's "two cores" could be better for our use. It should be treated differently for courses with no specific cultural features, like universal courses, and course with a certain 
philosophical concept or with strong cultural characteristics. The former can be completely original materials borrowed from the West, such as math management, financial accounting and international commercial law. But the latter should take the China market culture as the main content, such as management, marketing, consumer behavior, etc., to form a unique style of teaching discipline. ${ }^{[12]}$

Teaching should be based on course content to design appropriate teaching mode. For example, business English teaching can integrate manage knowledge, management practice into translation, writing and video case teaching, forming the "listening- management- speaking" mode. ${ }^{[13]}$

China 's MBA education moves towards internationalization, not only in the use of materials, structure and teaching methods of teachers, the most obvious is the source of students, teaching approaches and the internationalization of Chinese case development. The social development promotes China's MBA education, the emergence of "Three Lots" phenomenon, resulting in the combination of localization and internationalization trend becoming increasingly clear ${ }^{[14]}$. Trough designing professional, specialized projects, it enhances its international competitiveness. ${ }^{[15]}[16]$

Although the ubiquitous and concerning Chinese MBA education "six lots, six bits" problem ${ }^{[16]}$ has changed, but still not been completely solved, including teachers, textbooks and case studies, teaching content, especially the lack of "soft" courses and conformity courses, inter-regional and inter-school conditions, management varying greatly and so on. ${ }^{[2]}{ }^{[10]}$ These are the soft shortcomings of China's MBA program development.

\section{Introduction to foreign research}

MBA education in foreign literature research achievements mostly from the United States and Europe, so a small amount from Malaysia and Australia, which consider constructing multi-channel communication platform is very important, including communication platform between teachers and students, group learning, and a broad and diverse club activities lasting alumni network. ${ }^{[17]}{ }^{[18}{ }^{[19]}$ Rich in content and form of teaching should focus on interdisciplinary education, using evidence-based management of teaching, small class teaching and innovative thinking specialty training approach. [17] [20] [21] [22] Meanwhile, the use of modern network platform to carry out network remote MBA education can improve the limited amount of information face to face teaching , time constraints and other issues, to improve the effectiveness of classroom discussion. ${ }^{\text {[23] [24] }}$ [25] [26] [27] Through in-depth understanding of network status and satisfaction with distance learning student awareness of the impact of the situation, you can get a better resource methods. ${ }^{[28][29]}$

Different programs use different teaching methods have different effects on learning, learning class size also affect learning. Some researchers use factor analysis and principal component analysis, from a student perspective on teaching effectiveness, self-learning, distance education media three dependent variables were evaluated. Analysis teaching effectiveness, mutual selflearning and social skills impacts from two aspects of teachers and students, and a variety of educational activities for the exchange of classified classes and professors class. [28] 10 regard to satisfaction of the dependent variable for the analysis, and correlation analysis 22 from the perspective of the argument. Studies suggest that teachers instructive role to guide the greatest impact on teaching effectiveness. ${ }^{[29]}$

In summary, the foreign countries have already launched an empirical study MBA teaching effectiveness, while domestic research largely confined to the macro level, very little empirical research. Therefore, empirical research on the effect of China's MBA education is necessary.

\section{The Issue AND Use OF TEACHING METHODS}

\section{A. Introduction of the used teaching methods}

This study gets help from the platform that MBA core curriculum "Marketing Management”. Available only in the course of my school used a variety of teaching methods ( see Table 1 ) the validity of the results to improve the overall quality of students, but also to help the results to help design more effective teaching methods using the program

In addition to the common lectures, discussions, research propositions, case studies and self-study methods, including experimental simulation, and also increased the report writing and concluding remarks form of communication efforts, teaching methodology more perfect. 
TABLE I. TEACHING METHODS AND INSTRUCTIONS FOR MARKETING MANAGEMENT COURSES

\begin{tabular}{|c|c|c|}
\hline No. & Methods & The main purpose of teaching methods \\
\hline 1 & Lecture (Lec) & Marketing management decision-making system of the basic theory and management thinking \\
\hline 2 & Issues Discussed (ID) & During lectures combine knowledge of marketing management to discuss events happening today \\
\hline 3 & Proposition (Pro) & $\begin{array}{l}\text { Give a study involving more theoretical knowledge of the proposition, the use of other means of brainstorming } \\
\text { discussion system }\end{array}$ \\
\hline 4 & Case Study (CS) & $\begin{array}{l}\text { Usethe information given in the diagnosis of its business management, or discuss possible solutions marketing } \\
\text { decisions }\end{array}$ \\
\hline 5 & $\begin{array}{l}\text { Experimental Simulation } \\
\qquad \text { (ES) }\end{array}$ & $\begin{array}{l}\text { Simulation training students to compete marketing decision system application knowledge, unity and } \\
\text { cooperation, and problem solving ability of the comprehensive }\end{array}$ \\
\hline 6 & Report Writing (RW) & $\begin{array}{l}\text { Sort of marketing knowledge base management, improve writing skills students design solutions to solve } \\
\text { problems, exercise their relevance analysis and logical reasoning }\end{array}$ \\
\hline 7 & Concluding (Con) & Exercise the students the ability to summarize, and to learn more standardized writing requirements \\
\hline 8 & Self-study (Sel) & Put knowledge together by themselves, or knowledge of the relevant decision-making discussions need to learn \\
\hline
\end{tabular}

"Discussion" and "research propositions" are combined with the current socio-economic activities carried out in the new trends in marketing and management issues for discussion. The difference is that the former is a combination of primary teaching process knowledge point for discussion, the latter after a chapter or chapters on the end to give a larger proposition to start. "Case Study" in a given business situation under the case, including the detailed background information, to analyze information in a particular environment decision results obtained , the case can be very flexible, ample classroom time under the degree and amount of learning lessons fixed .

Based on the case study, "Experimental Simulation" introduces the MBA students into a more real way to learn to manage the decision-making situations go. This requires the help of computer software lab to conduct. Meanwhile, in order to create a more realistic operation of the market situation, the participants are divided into several groups to set up a company, and their commitment to the company in different functions work, immersive marketing management decision to compete in a specific "market" environment. In some ways, the "experimental simulation" is also a teaching experience, more immersive than the usual form of "case study”.

"Report writing" which can control the scientific and systematic management decision-making process, is necessary supporting ways to "experimental simulation". The basic course content includes marketing decisions and annual report summary report in two parts. The purpose is to allow students to master the basic content of more systematic reporting of marketing decisions, requirements, writing formats, and the use of marketing data analysis for decision-making.

Not only to the "experimental simulation", "Concluding remarks" are also required as supporting use of "case studies". After the end of the teaching activities of a large discussion or "simulation experiments" conducted, speakers represent groups or companies, which exercise the participants decision-making data aggregation, finishing ideas, content presentation, PPT production and time to master.

\section{B. Issues and decomposition}

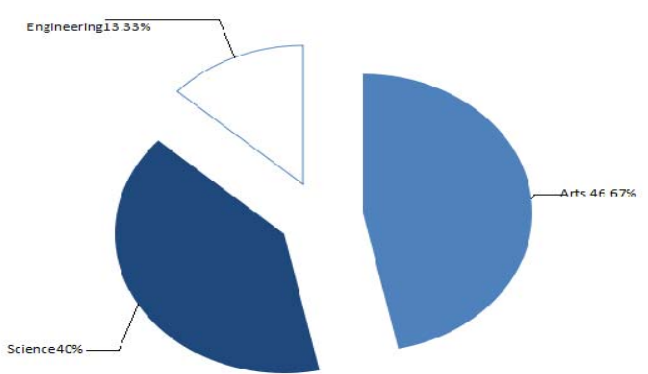

Figure 1.

The ultimate goal of marketing management course is to teach MBA students how to master and flexibly applied to analyze and solve practical problems with theory and methods of marketing and management , and improve the ability of its comprehensive management, judgment and decision-making. Whether a variety of teaching methods and means used in marketing and management courses are effective or not, and how its popularity is as such issues are of concern.

The use of effects and the quality of teaching methods can grasp recognition system expertise from the students, the ability to increase the degree of expertise in the application, or to make up for lack of knowledge in the application, enhance the ability to obtain information, to improve the ability of the system to analyze problems and reports examine aspects of writing ability.

\section{BASIC ASSUMPTIONS AND CONDITIONS}

\section{A. Research assumptions and conditions}

The purpose of this study is to find the effect of teaching methods used by attending courses. Thus, the survey of empirical research is among MBA students who participate in the marketing and management courses. Although the survey is complete marketing management MBA students participated in the entire teaching process. According to "feel three mechanisms" theory of consumer psychology, 
anyone would more or less selectively misinterpreted problems, so we must make the appropriate assumptions.

Assumption 1: Respondents who understand and answer questions is rational;

Assumption 2: Course learning process and full participation of each of the respondents are understandable;

Hypothesis 3: Design and use a variety of teaching methods for each student are acceptable.

\section{B. Questionnaire design and the basic situation of respondents}

Survey design shall include five parts. Clearly inform respondents of the survey objectives and topics, express needs of the survey respondents fit , but also the basic information of respondents, the survey participants understand the main content and other requirements .

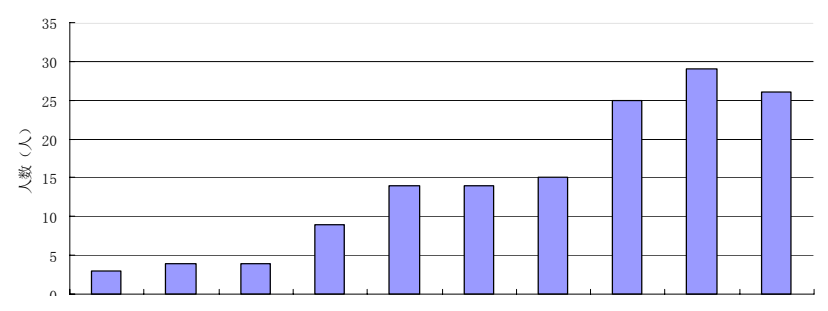

Figure 2. Respondents' work position

The survey involved a total of six classes who have been taught marketing and management courses, which total number is 182. 156 questionnaires were recovered, of which 143 valid questionnaires. The response rate reached $85.71 \%$, with a pass rate of $91.67 \%$. The undergraduate academic structure shows in Figure 1. The distribution of the respondents work position is in Figure 2. 5-8 years in senior management positions and seniority of staff in science and engineering undergraduate background is more than most, eight years of service in any of the company's senior executives.

The distribution of the respondents units are wide, mining, electronics, finance, government agencies and research institutes and others. Men slightly more than women, aged mainly concentrated in the (accounting for $89.51 \%$ ) between 26 to 40 years old, work experience mainly for more than 5 years (accounting for $71.33 \%$ ).

\section{ANALYSIS OF THE RELATIONSHIP BETWEEN TEACHING METHODS AND OVERALL QUALITY}

Through the analysis of the survey data found that a variety of teaching methods to enhance the quality of MBA students on the role is different, with the same teaching methods to the MBA students also differ.

\section{A. Analysis the relationship between teaching methods and enhancement of professional knowledge}

The relationship for MBA students in teaching methods and professional knowledge systems expertise to master (Figure 3), the greatest degree of influence is "lectures" (accounting for $32.17 \%$ ), the first three rows of the impact is not too great a difference . "Case study" and "simulation experiments" were $27.27 \%$ and $24.48 \%$. It respondents that generally believe in the system should acquire specialized knowledge -based classroom teaching, case teaching supplement.

TABLE II. SELECT PROPORTION OF ALL AGES UNIT:\%

\begin{tabular}{ccccc}
\hline Methods & $\begin{array}{c}25 \text { years } \\
\text { old }\end{array}$ & $\begin{array}{c}26-30 \\
\text { years old }\end{array}$ & $\begin{array}{c}31-40 \\
\text { years } \\
\text { old }\end{array}$ & $\begin{array}{c}\text { over 41 } \\
\text { years } \\
\text { old }\end{array}$ \\
\hline Lecture & 54.55 & 28.33 & 30.88 & 50.00 \\
Case Study & 9.09 & 26.67 & 30.88 & 25.00 \\
$\begin{array}{c}\text { Experimental } \\
\text { Simulation }\end{array}$ & 9.09 & 26.67 & 26.47 & 0 \\
\hline
\end{tabular}

In addition, that "lectures" the role of teaching methods is quite different for students in different sections of seniority. More than eight years of service trainees to choose the highest proportion (46\%),5-8 years of service trainees to choose "experimental simulation" the highest percentage(36.59\%), the difference between select“ experimental simulation” section of each student's little seniority. These three methods of teaching are different for MBA students of different ages for its recognition of the extent (see Table 2). But the impact of gender is not.

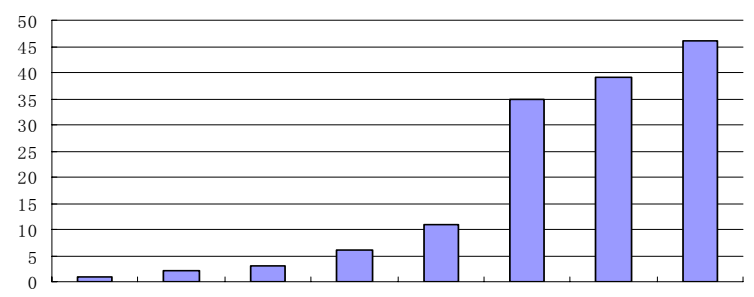

Figure 3.

Different segments seniority, age and gender of the participants believed that systematically acquiring specialized knowledge, "lectures" is the best way. While "case studies" and "simulation experiments" can help them more effectively understand and grasp, the former can't be replaced.

\section{B. Analysis the relationship between teaching methods and application}

In the aspect of improvement the ability of expertise applied, to select the highest probability of the first three teaching methods vary greatly (Figure 4)."Experimental simulation" get the highest recognition (47.55\%), which is more than the second place "case study" approach of the nearly 20\%. Therefore, the "experimental simulation" is very effective teaching methods to help them to understand, learn and use marketing and management expertise. 


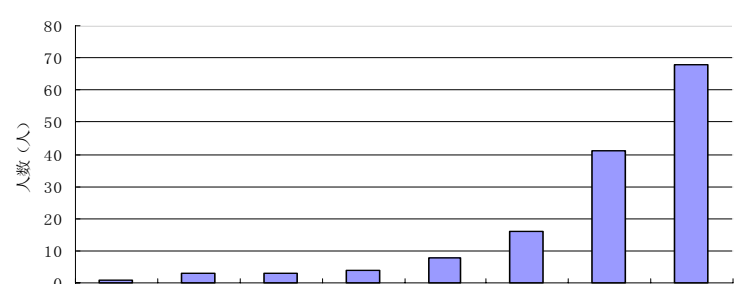

Figure 4. Teaching methods and applications expertise

But the MBA students of different ages and seniority segments are quite different to the "experimental simulation" teaching methods acceptable levels, which over 8 years seniority highest recognition between the ages of 31-40. From Table 3, the younger student does not endorse "discussion", rather elderly segment does not endorse “experimental simulation” mode.

Table III. Select Proportion Of All Ages ～UNIT:\%

\begin{tabular}{ccccc}
\hline Methods & $\begin{array}{c}25 \\
\text { years } \\
\text { old }\end{array}$ & $\begin{array}{c}26-30 \\
\text { years } \\
\text { old }\end{array}$ & $\begin{array}{c}31-40 \\
\text { years } \\
\text { old }\end{array}$ & $\begin{array}{c}\text { over 41 } \\
\text { years } \\
\text { old }\end{array}$ \\
\hline $\begin{array}{c}\text { Experimental } \\
\text { simulation }\end{array}$ & 36.36 & 46.67 & 52.94 & 0 \\
Case Study & 9.09 & 25.00 & 32.35 & 50.00 \\
Discussion & 0 & 16. & 7.3 & 25.00 \\
& & 67 & 5 & \\
\hline
\end{tabular}

C. Analysis the relationship between teaching methods and making up for shortage

In the mastery and application expertise to make up the shortage, the choice of a variety of teaching methods are involved (Figure 5), clearly shows that compared to the previous two questions to select high dispersion. But the overall trend is that the "discussion" is the best way to effect (23.78\%), and ranked second and third, "lectures" (18.89\%), "Case Study" (16.78\%) method is not very different. It shows that these three basic teaching methods work for different people differently. This can also be reflected differences that participants from different segments considered insufficient to make up of service most appropriate way (see Table 4).

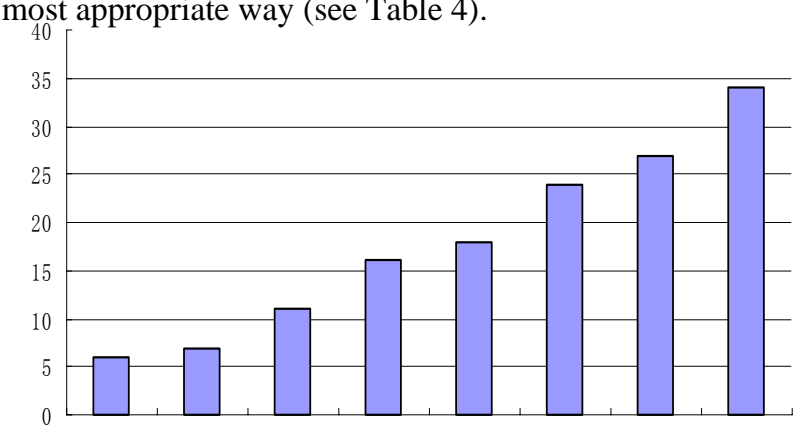

Figure 5. Teaching methods and compensate for shortage
In terms of that "discussion", to make up for deficiencies is the best way. Five years seniority students surveyed $41 \%$ of the total rank first. 41 years or older students think the best approach is "lecture" (50\%). For "Experimental simulation", with age at 40 years of age increases demand increasing trend. This may be the cause of the rapid increase in the population is at times, hoping to more quickly and effectively grasp and application expertise.

TABle IV. SElect Proportion Of All Seniority ～Unit:\%

\begin{tabular}{cccc}
\hline Methods & 2-5years & $\begin{array}{c}5-8 \\
\text { years }\end{array}$ & over8 years \\
\hline Lecture & 14.63 & 26.19 & 16.39 \\
Discussion & 34.15 & 19.05 & 19.67 \\
Proposition Research & 2.44 & 4.76 & 6.56 \\
Experimental & 12.2 & 11.9 & 13.12 \\
Simulation & & & \\
Case Study & 9.76 & 16.67 & 21.31 \\
Report Writing & 9.76 & 7.14 & 6.56 \\
Concluding Remarks & 9.76 & 11.9 & 11.48 \\
Self Study & 7.32 & 2.38 & 3.28 \\
\hline
\end{tabular}

D. Greatest achievement

In order to understand the respondent's "inadequate", the survey designed a problem that "What is your greatest achievement". Who select "enhance the ability of the system to analyze problems" accounted for $58.04 \%$ ( Figure 6 ) ,which is far more than the proportion choose other options .It shows that systematic analysis of professional issues may be the main weaknesses of the trainees. While "report writing capabilities" and "ability to work with others" accounted for $30.07 \%$ of the total.

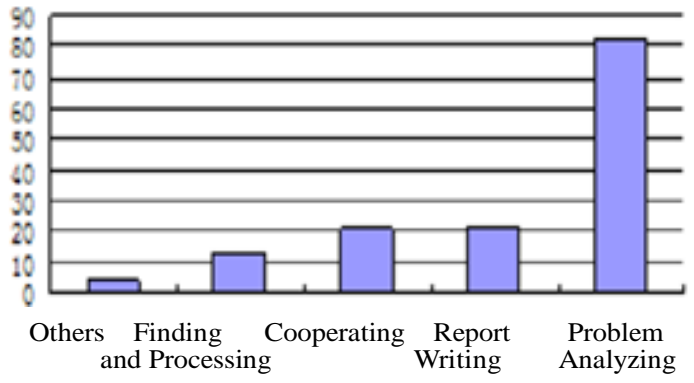

Figure 6. Greatest achievement

In this option, the length of service in more than eight years accounted for 43\%, 5-8 years and less than 5 years accounted for $28 \%$ and $29 \%$. The total number of people who choose the proportion of the population, regardless of which seniority segment more than half of the respondents. Choose the "ability to cooperate with others to enhance" the largest population below the age of 25 ( $27.27 \%$ ), indicating that the age of the students through the learning process of exchange and cooperation platform to benefit the most, "Experimental simulation" approach is the best teaching platform . 


\section{ADAPTABILITY OF TEACHING METHODS}

In order to exclude a variety of teaching methods for different groups of people targeted, with the understanding of the overall evaluation of teaching methods designed problem that "The way teaching is your favorite". On this issue, select the "experimental simulation" method highest proportion (49.65\%), far more than other items. And three of the former are more than $80 \%$ of GDP in total (Figure 7). Maybe it take more time after class, nobody select "report writing" mode. Students who selected "Proposition research" in a different segment has seniority, but mainly between $30-40$ years of age and 25 years of age, $75 \%$ of these people in front of the problem also select the item, such as a variety of teaching methods for their systematic when acquire specialized knowledge, and the application of knowledge to enhance the ability of the most effective methods. Each segment selector seniority "lectures" approach, the age and gender of the students are. For "Concluding remarks" and "discussion", the participants do not choose who ages 41 years and older, while the other age groups roughly equal proportions. For the "case study" option clearly showed a positive correlation between age and popularity.

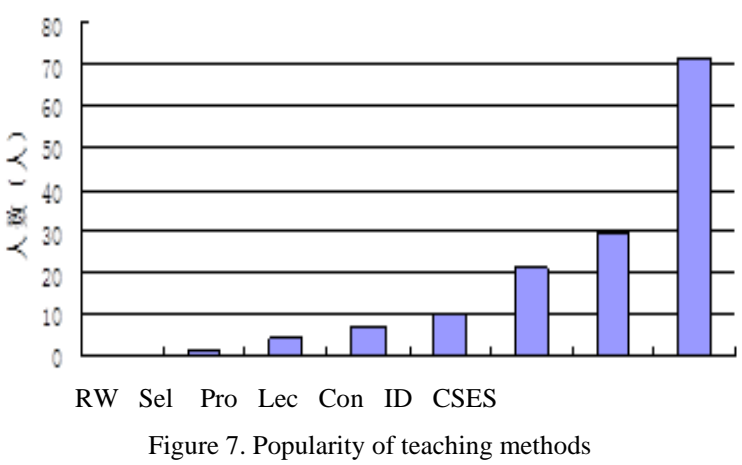

\section{CONCLUSIONS}

In summary, the different length of service and age of MBA students, recognized the extent of the impact of a variety of teaching methods used to improve their overall quality or changes to be different. But the difference in gender was not significant. The rate that young MBA students choose for the "discussion", "concluding remarks" is low, which shows that younger students are not very good at description of the problem needs to react quickly and clearly express their intent. Old MBA students support the use of other teachers to participate in and guide, such as "lectures", "case studies", and acceptance of lower marketing decisions and annual summary reports written. This may be related in middle management or senior management positions, which need to spend more time after lesson. They can't spare more time to participate.

The relationship between "Classroom", "discussion" and "case study" and the "ability to make up for lack of" for any length of service or age students have played a fundamental role, so these three MBA teaching process using the most basic traditional teaching methods to use as long as the comprehensive, we can ensure the basic validity of teaching activities. Although "Experimental simulation" shows an increasing trend with increasing age and needs, allowing students more in-depth , systematic strengthening application practice, it should also pay attention to cultivating the object hierarchy, if the validity of the EMBA education approach might worse than " case study ."

Variety of teaching methods used in marketing and management courses have their own characteristics, which can give full play to their respective advantages with systemic and integrated use of them, making MBA students more effectively improve the overall application expertise , systems analysis capability professional issues .

The survey was limited to MBA students who have experienced marketing and management courses, and got involved in the use of these teaching methods. So the results of the analysis are limited to only one state. If you can get the information about the people who participate in the management course that did not used these methods, you can get comparative data.Then the analysis results will be more effective.

\section{ACKNOWLEDGEMENT}

This research was financially supported by the China University of Geosciences (Beijing), Discipline Project (2013-2014) to support the 2012.

\section{REFERENCES}

[1] Que Shihua. Nankai MBA Innovative Way [J]. Chinese New Times, 2011, (11):85 -87

[2] Feng Jiaxue. On the road-Speak to General Steering Committee of the National MBA Education secretary [J]. Chinese New Times, 2011, (11):65 -68.

[3] Feng Jiaxue. MBA train future leaders with comprehensive management capabilities in Tsinghua [J]. Chinese new Times, 2011, (11):79 -80.

[4] Lin Yifu, What kind of MBA does China need[J] .21 Century Business Review , 2005, (6):136 -137.

[5] Ministry of Education, the National Development and Reform Commission, Ministry of Finance. Opinions on deepen the reform of $\begin{array}{lll}\text { graduate } & \text { education }\end{array}$ Http://www.moe.edu.cn/publicfiles/business/htmlfiles/moe/A22_zcw $\mathrm{j} / 201307 / 154118$. html

[6] Liu Fucheng,Hua Bin. Construction of MBA teaching practice evaluation index system[J]. East China Economic Management, 2010,24 (12):157 -160.

[7] Duan Dan. Advocate ideal MBA training to improve the quality of training mode [J]. Guangdong University of Business Studies, 2009, (6):94 -97.

[8] Jiao Shengli. MBA education innovation based on service quality gap model - Taking Tsinghua MBA version of the change as an example[J]. Chinese collective economy, 2009, ( 28 ) :178 -179.

[9] Shi Fang, Xia Jiansheng, Chen Tiejun. MBA Education Program Features foster scientific development [J]. Higher Education and the Economy, 2010,23 (3) :58 -62.

[10] Yi Liu. Restricting the development of China's MBA education bottleneck[J]. Entrepreneurs, 2003, (3) :11 -13.

[11] Qian Yingyi. Tsinghua University: Importance of soft skills education[J]. Human Resources , 2010, (1) :10 -11.

[12] Wang Jianguo. New Exploration on Chinese MBA education development strategy[J]. Modern Enterprise Education, 2001, (11):10 $-11$. 
[13] Sun Chaoping, Liu Cui, Zhao Huifang. Innovation and practice MBA Business English teaching mode[J]. Hefei University of Technology (Social Science Edition), 2010,24 (6) :158 -162.

[14] Cui Hongwei. Localization and internationalization of Chinese MBA Education[J]. Foreign entrepreneurs, 2012, (1):37 -39.

[15] Li Jingwen. Development and Innovation MBA education in China[J]. Chinese High-tech Zone, 2002, (6):40 -41.

[16] Li Jie, Xiao Yongji, Zhang Zhijun. Train Chinese MBA core competitiveness[J]. Manager, 2002, (8):96 -97.

[17] Cheng Sq, Han F. On the Innovative Talents Training Mode of American Business Schools: Based on the MBA Programs in Four Business Schools[C]. ICEEM 2012: 2012 2ND INTERNATIONAL CONFERENCE ON ECONOMIC, EDUCATION AND MANAGEMENT , 2012,1 : 500-504

[18] Krass D, Ovchinnikov A. The University of Toronto's Rotman School of Management uses management science to create MBA study groups[J]. INTERFACES , 2006,36(2) : 126-137

[19] Keller C, Kros J. Teaching communication in an MBA operations research/management science course[J]. JOURNAL OF THE OPERATIONAL RESEARCH SOCIETY , 2000,51(12) : 14331439

[20] Charlier S. D , Brown, et al. Teaching Evidence-Based Management in MBA Programs: What Evidence Is There? [J] ACADEMY OF MANAGEMENT LEARNING \& EDUCATION ,2011,10(2):222-236

[21] Zhang Cj. Study on Characteristic Development of MBA Education in Western National Universities[C]. PROCEEDINGS OF 2010 INTERNATIONAL CONFERENCE ON MANAGEMENT SCIENCE AND ENGINEERING , 2010 : 454-458
[22] Zhao W, Liu Gw. MBA teaching and the cultivation of creative thinking ability[J]. HUMAN RESOURCES MANAGEMENT IN THE KNOWLEDGE ECONOMY ERA , 2008 : 398-402

[23] Muthuveloo R, Ping T.A. TEACHING AND LEARNING OF AN ONLINE MASTER IN BUSINESS ADMINISTRATION (MBA) COURSE: EXPERIENCE FROM MALAYSIA[C]. 5TH INTERNATIONAL CONFERENCE OF EDUCATION, RESEARCH AND INNOVATION , 2012 : 2816-2823

[24] Kim M.R, Kim T.U , Kim Jaehyoun. A Study on e-Learner Satisfaction: The Case of Online MBA Program[C].INFORMATION-AN INTERNATIONAL INTERDISCIPLINARY JOURNAL , 2011,14(7) : 2487-2498

[25] Bentley Ym, Habte S. ELearning Expectations and Experiences of Executive MBA Students[J]. PROCEEDINGS OF THE 9TH EUROPEAN CONFERENCE ON E-LEARNING , 2010,1 : 72-80

[26] Arbaugh J.B. An exploratory study of the effects of gender on student learning and class participation in an internet-based MBA course.[C] MANAGEMENT LEARNING , 2000,31(4) : 503-519

[27] Glenn D. Priming for Modules: A Case Study Evaluation of 'PreWorkshop' Online Resources for an Executive MBA Course[C]. PROCEEDINGS OF THE 10TH EUROPEAN CONFERENCE ON E-LEARNING , 2011,1-2 : 195-202

[28] Arbaugh J.B. Does academic discipline moderate CoI-course outcomes relationships in online MBA courses?[J]. INTERNET AND HIGHER EDUCATION , 2013,17 : 16-28

[29] Arbaugh J.B. Sage, guide, both, or even more? An examination of instructor activity in online MBA courses[C]. COMPUTERS \& EDUCATION 